
AleksandarTrifunović
DOI:https://doi.org/10.18485/slovenika.2021.7.1.6 Univerza v Ljubljani
UDK: 811.163.41'276.6:636(234.3/.4)
Filozofska fakulteta
$81 ’ 373.614(234.3 / .4)$
Slovenija
aleksandartrifunovic3@gmail.com
Pregledni rad

\title{
O etimologiji izbranih besed iz pastirske terminologije karpatsko-balkanskega areala
}

Povzetek

Transhumantno pašništvo je do dvajsetega stoletja za nekatere prebivalce Balkanskega polotoka pomenilo glavni vir dohodkov. Stoletja se je vlaško ljudstvo na območju Balkana in Karpatov vsako leto selilo med poletnimi in zimskimi pašniki. Takšen način življenja je neizogibno pripeljal tudi do stika transhumantih pastirjev z drugimi ljudstvi. Rezultat teh stikov so kulturne in jezikovne izmenjave, ki so opazne tudi na ravni leksike. Prispevek obravnava izbrane besede iz pastirske terminologije karpatsko-balkanskega areala.

Ključne besede:Vlahi, pastirji, transhumanca, Balkan, karpatsko-balkanski areal

$\begin{array}{ll}\text { Seznam okrajšav } \\ \text { alb. } & \text { albansko } \\ \text { arom. } & \text { aromunsko } \\ \text { av. } & \text { avestijsko } \\ \text { ben. } & \text { beneško } \\ \text { bolg. } & \text { bolgarsko } \\ \text { cslovan. } & \text { cerkvenoslovansko } \\ \text { češ. } & \text { češko } \\ \text { čiš. } & \text { čiško } \\ \text { got. } & \text { gotsko } \\ \text { ide. } & \text { (pra)indoevropsko } \\ \text { it. } & \text { italijansko } \\ \text { lat. } & \text { latinsko } \\ \text { lit. } & \text { litovsko }\end{array}$




$\begin{array}{ll}\text { madž. } & \text { madžarsko } \\ \text { mak. } & \text { makedonsko } \\ \text { nar. } & \text { narečno } \\ \text { ngr. } & \text { novogrško } \\ \text { perz. } & \text { perzijsko } \\ \text { polj. } & \text { poljsko } \\ \text { psl. } & \text { praslovansko } \\ \text { rom. } & \text { romunsko } \\ \text { sln. } & \text { slovensko } \\ \text { slš. } & \text { slovaško } \\ \text { srb. } & \text { srbsko } \\ \text { srb.-hrv. } & \text { srbohrvaško } \\ \text { srvnem. } & \text { starovisokonemško } \\ \text { stcsl. } & \text { starocerkvenoslovansko } \\ \text { tur. } & \text { turško }\end{array}$

\section{Uvod}

Pastirstvo je za prebivalce gorskih območij, kjer tla niso rodovitna in klima ni primerna za poljedelstvo, dolgo bilo najpomembnejša (če ne celo edina) gospodarska panoga (Luković 2015, 47). Eden od načinov prilagoditve na takšno okolje je transhumantno pašništvo, sezonska selitev ljudi in živine na poletne ter zimske pašnike (Luković 2015, 50). Pastirstvo je dolgo bilo del vsakdana velikega dela balkanskega in karpatskega prebivalstva, $v$ nekaterih delih Balkana in Karpatov pa so sledi tovrstnega življenja še vedno prisotne (Luković 2015, 62). Na Slovenskem je ovčereja značilna predvsem za Kras, Istro, Bovško, Belo krajino in Pivško ter je imela pomembno vlogo že od časa naseljevanja Slovanov na to ozemlje naprej (Smerdel 1989, 15). V nasprotju z Balkanom in Karpati, kjer še vedno obstajajo sledi transhumance, se je ta na Slovenskem bližala koncu že v drugi polovici 18. stoletja (Smerdel 1989, 17). Zaradi pomena, ki ga je pastirstvo imelo na omenjenih območjih, je treba pozornost nameniti tudi pastirski terminologiji, ki zajema poimenovanja domačih živali, objektov za namestitev pastirjev in živali, poimenovanja za mleko in mlečne izdelke, volno in njeno predelavo, medmete, ki so se uporabljali za privabljanje in odganjanje živali ipd.

Najbolj znani pastirji s karpatsko-balkanskega območja so Vlahi, ki so se nemoteno selili med svojimi pašniki in so bili v stiku z lokalnim prebivalstvom ter drugimi družbenimi skupinami. Sčasoma so postali del lokalnega prebivalstva in v njihovem jeziku pustili svoje sledi (Radan in dr. 2016, 60). 


\section{Metodologija}

Prispevek je razdeljen na dve celoti: prva je posvečena Vlahom, romaniziranemu balkanskemu prebivalstvu, ki se je od antike do prve polovice 20. stoletja množično ukvarjalo $\mathrm{s}$ transhumantnim pašništvom (Luković 2015, 62) in tako stopalo v stike z različnimi skupnostmi. Slednji so pripeljali do medsebojne kulturne izmenjave in posledično do vzajemnega prevzemanja besed (Kahl 2007, 157); drugi del je posvečen besedam iz pastirske terminologije oziroma besedam karpatsko-balkanskega areala, ki se pojavljajo v večini jezikov Balkanskega polotoka (predvsem v albanščini, osrednji južni slovanščini, makedonščini, bolgarščini, aromunščini in dakoromunščini) ter $v$ ukrajinščini, slovaščini in poljščini.

Seznam besed, ki bodo obravnavane $v$ tem prispevku, je sestavljen na podlagi Splošnokarpatskega dialektološkega atlasa, zvezek 2 (Общекарпатский диялектологический атлас, выпуск 2), Malega balkanskega dialektološkega atlasa, knjiga III (Малый диалектологический атлас балканских языков, Tом III) in Slovarja balkanizmov v dialektih Egejske Makedonije (Stownik batkanizmów w dialektach Macedonii Egejskiej). Kriterij pri izbiri besed je bil, da besedo najdemo v vsaj štirih jezikih med zgoraj navedenimi.

Besede so navedene $v$ knjižni obliki, s pomenom, ki ga imajo $v$ knjižnih jezikih. Narečne oblike so navedene le v primeru, če je njihov pomen drugačen od tistega, ki ga ima beseda $v$ knjižnem jeziku, ali če se besede pojavijo samo $v$ narečju.

$\checkmark$ prispevku poskušam razložiti, kateri jezik predstavlja izhodišče za določeno besedo, in dokazati, da se izposojanje določenih besed ujema s selitvami Vlahov. $V$ ta namen bom uporabil komparativno metodo za primerjanje besed $v$ jezikih karpatsko-balkanskega areala, za rekonstrukcijo besed pa metodo rekonstrukcije.

Gesla iz osrednje južne slovanščine so zaradi uporabljene literature označena s terminom srbohrvaški zaradi, zapisana pa so v latinici. Gesla $\checkmark$ albanskem, makedonskem, bolgarskem in romunskem jeziku so navedena $v$ nedoločni obliki.

\section{Vlahi}

Ime Vlahi je etnonim, natančneje eksonim, za paleobalkansko romanizirano prebivalstvo, $s$ katerim so Južni Slovani prišli v stik ob prihodu na Balkan (Mirdita 2007, 256). Etnonim se prvič pojavi v pismu bizantinskega cesarja Bazilija II. Ubijalca Bolgarov leta 980 (Dölger v Mutavdžić 2019,69).

Etnonim izhaja iz imena velikega keltskega naroda Volcae (Mutavdžić 2019, 69). Slovanski jeziki naj bi prevzeli ta etnonim iz got. ${ }^{*}$ Walhs, srvnem. walah, walh 'tujec, Kelt, Roman', pri čemer je prišlo do splošno- 
slovanskega premeta jezičnikov: cslovan. vlahı, srb.-hrv. Vläh 'Roman, Italijan', slš. Vlach, polj. Włoch 'Roman', ukr. Влох 'Romun'. Na podlagi izpričanih besed lahko rekonstruiramo psl. *volchъ (Bezlaj II 1982, 119-120, Skok III 1973, 608).

Vlahi se niso ukvarjali s poljedelstvom v veliki meri (Mutavdžić 2019, 71), zato pa se je romanizirano prebivalstvo z obeh strani Donave (Dakoromuni in Aromuni) že od antike ukvarjalo s pastirstvom, o čemer priča tudi pastirska terminologija $v$ romunččini in aromunščini, ki je latinskega izvora (Micle 2013, 4). Njihov način življenja - transhumantno pašništvo - in privilegiji, ki so jih imeli na območjih različnih balkanskih držav, so Vlahom omogočili nemoteno gibanje po Balkanskem polotoku. $O$ njihovih premikih pričajo tudi toponimi $v$ današnji Srbiji (Stari Vlah, Vlasina, Vlašic), Bosni in Hercegovini (Vlašic), Sloveniji (Lahovna, Lašče, Laško, Lašna, Lahovče) (Snoj 2009, 227)1 in Grčiji

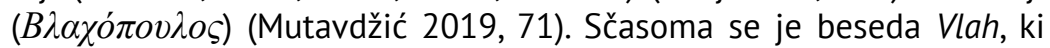
je prvotno uporabljana samo kot etnonim, razširila na vse ljudi, ki so se ukvarjali s pastirstvom, ne glede na njihovo etnično pripadnost, ter postala sinonim za pastirja. (Mirdita 2007, 257).

Vlaška kolonizacija severnega dela Karpatov se je začela v 13. stoletju. S seboj so prinesli pastirsko kulturo, ki je bila lokalnemu prebivalstvu neznana (Oczko 2016, 151). O tem pričajo toponimi v pokrajinah južne Poljske kot tudi pastirska terminologija (Oczko 2016).

\subsection{Vlaška transhumanca}

Poti vlaške transhumance lahko razdelimo na dva velika dela: aromunski in dakoromunski.

Dakoromunski pastirji so se selili med zimskimi pašniki $v$ dolini reke Donave, v Banatu, Dobrudži in Moldaviji ter poletnimi na Karpatih (Micle 2013, 4). Aromunski pastirji pa so zimske pašnike imeli ob obali Jadranskega morja, v Sremu, Slavoniji, v Tesaliji in južni Albaniji, medtem ko so poletne imeli v Dinarskem in Balkanskem gorovju ter Pindskem gorstvu in v Istri, segali pa so celo do Kolpe (Micle 2013, 4).

\footnotetext{
${ }^{1}$ Tudi hidronim Lahinja.
} 


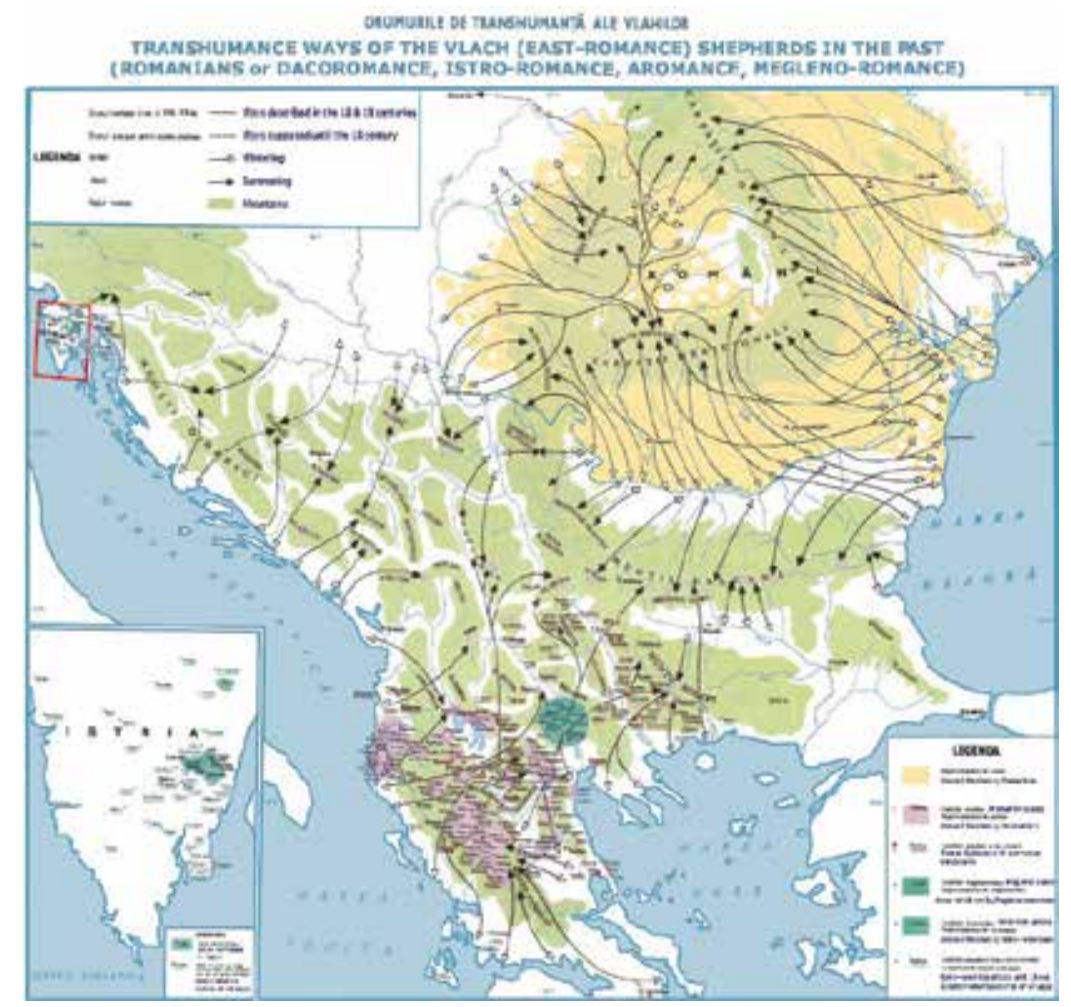

Slika 1. Poti vlaške transhumance (Bogdan 2011, 46).

Beseda Vlah oz. vlah ima danes v jezikih karpatsko-balkanskega areala različne pomene, in sicer:

1) v albanščini (vlláh) označuje govorca romaniziranega ljudstva, ki se je ukvarjalo predvsem s pastirstvom;

2) na srbohrvaškem območju (Vläh in vläh) označuje:

a) živinorejca iz notranjosti Balkana v srednjem veku,

b) prebivalca romunske pokrajine Vlaške,

c) (slabš.) kristjana iz BiH (zlasti Srba),

d) osebo romanskega rodu na levem bregu Donave (Homolje, Stig);

3) v makedonščini (Влах) označuje tako Romuna kot Vlaha;

4) v bolgarščini (Влах) označuje tako Romuna kot Aromuna;

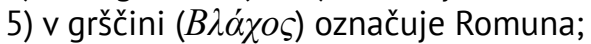

6) $\vee$ romunščini (Valáh) označuje prebivalca Vlaške (Mutavdžić 2019, 70);

7) v slovaščini označuje prebivalca pokrajine Vlaške v Romuniji ( Valach) in pastirja (valach);

8) v ukrajinščini (Волóx) označuje prebivalca romunskih zgodovinskih pokrajin Vlaške, Oltenije, Besarabije, Moldavije in Transilvanije. 


\section{Pastirska terminologija}

Jeziki karpatsko-balkanskega areala sodijo $v$ različne jezikovne skupine in družine. $\vee$ srbski pastirski terminologiji prevladujejo besede slovanskega izvora, vendar $v$ njej lahko najdemo tudi besede omenjenega areala, zlasti za pomenska polja, ki niso značilna za Slovane (Bošnjaković 1985, 88; Rakić-Milojković 1993, 81; Radan in dr. 2016, 63). Domnevamo lahko, da je stanje podobno tudi v drugih slovanskih jezikih. Stiki Slovanov in drugih narod Balkana ter karpatske regije z ljudstvom, ki se je preživljalo z vzrejo živine, in prihod Turkov na Balkanski polotok so pripeljali do tega, da so se $\mathrm{v}$ jezikih pojavile nove besede, $\mathrm{ki}$ so bodisi sopomenke za že obstoječe besede (alb. barí : çoban 'pastir', srb.-hrv. pàstîr : čòban(in) 'pastir') bodisi pa gre za besede, ki so iz vsakdanje rabe izrinile že obstoječe (srb-hrv. vătra : òganj 'ogenj').

Klepikova (Klemenčič 2005, 30-31), ena od avtoric Splošnokarpatskega dialektološkega atlasa, razlikuje dva oziroma tri areale karpatske leksike:

- ozko karpatski areal, ki zajema ukrajinske, slovaške, poljske in češke govore, $v$ katerem se pojavljajo naslednji primeri:

*vakeša »bela ovca«, *bu(n)(d)z »svež ali le malo uležan ovčji sir, iz katerega delajo brindzo«, "žentica »sirotka iz ovčjega mleka«, " podišor "polica v hiši, kjer je spravljen sir in posoda«, morda tudi *komarnik »prostor, kjer so spravljeni mlečni izdelki« in *salaš »pastirsko bivališče; čreda«;

- karpatsko-balkanski areal, ki ga razdeli v dve skupini, in sicer:

a) areal, ki zajema poleg naštetih jezikov tudi romunščino, albanščino in grščino z naslednjimi besedami:

*kornut »žival z rogovi«, " balan »žival bele barve«, "tsark »ločeno mesto v hlevu«, "strunga »ozek prehod; staja za ovce; staja za krave«, *ryn(d)za »želodec prežvekovalca, iz katerega pridobivajo sirilo«;

b) areal, ki zajema tudi južnoslovanske jezike in v katerega sodijo naslednje besede:

${ }^{*} d z e r(a)$ »sirotka, ki ni namenjena nadaljnji predelavi«, ${ }^{*}$ kolastra »prvo mleko krave ali ovce po porodu«, "urda »skuta iz prekuhane sirotke«,

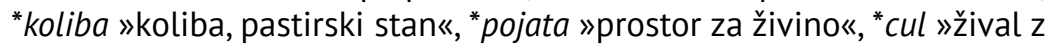
majhnimi ušesi ali brez njih« * $p(V) r c(-k)$ »neskopljen kozel ali koštrun« *bačija "pastirsko bivališče«, leksemi s korenom *var- in *syr- za označevanje različnih mlečnih izdelkov; "belica »ovca bele barve«; * $k$ lag ali " glag »sirilo«; " šut(k)(a) »brezroga ovca« * ${ }^{*}$ cap »kozel«, "košara, " staja.

Čeprav v svojem članku navaja, da se nekatere besede pojavljajo zgolj v srbskih narečjih, npr. *salaš, srb. sàlāš in *strunga, srb. nar. strònga (Klepikova 1975, 165, 167), bomo v nadaljevanju videli, da tovrstna razdelitev ni povsem točna, saj se omenjene besede pojavljajo tudi $v$ drugih južnoslovanskih jezikih (npr. oblika besede *salaš, a z drugačnim pomenom, kot ga ima beseda v čeških, poljskih, slovaških in ukrajinskih narečjih) ali pa se na širšem območju uporablja druga oblika besede 
(npr. *strunga, srb.-hrv. strüga). Hkrati je beseda *cap »kozel« označena kot beseda, ki se pojavlja tudi v južnoslovanskih jezikih, čeprav jo najdemo zgolj v kosovsko-resavskem narečju osrednje južne slovanščine (gl. Bošnjaković 1985, Stanišić 1995, Rakić-Milojković 1993). Pri tem je treba omeniti, da te besede ni niti v srbskih narečjih v Romuniji, čeprav se pojavlja tudi v romunskem jeziku (rom. ţap »kozel«) (Radan in dr. 2016).

\subsection{Karpatsko-balkanski areal in stanje na Slovenskem}

Prihod Turkov na Balkan je sprožil selitev ljudstev. Tako so se na območje Čičarije priselili govorci osrednječakavskega narečja, v južno Belo krajino pa so prišli govorci štokavskega narečja, ki se identificirajo kot Srbi (Šekli 2019, 10).

Čeprav slovenski jezik ne sodi v karpatsko-balkanski areal, se v določenih narečjih na Slovenskem, tako genetsko slovenskih (južnobelokranjsko narečje) ${ }^{2}$ kot genetsko neslovenskih (čiško narečje) in tudi v knjižni slovenščini, pojavljajo nekatere besede, ki so leksikalno sorodni $z$ besedami v omenjenem arealu. $V$ nadaljevanju bomo videli, ali je pojav teh besed povezan s selitvami transhumantnih pastirjev ali gre za posledico stikov Slovencev in drugih narodov (Furlanov, Italijanov in Madžarov).

\section{2 "balega »gnoj《}

Pojavlja se le v srb.hrv. bälega, mak. балегa, čiš. baloga rom. bălegă, alb. bajgë, v drugih karpatsko-balkanskih jezikih je ni (Stanišić 1995, 67). Obstajali so poskusi etimološke razlage besede - romunski jezikoslovec Hasdeu jo je poskusil povezati s tatarsko besedo balhas, ki ima isti pomen, ampak je ta razlaga fonetično nevzdržna, zato jo Skok uvršča v besede ilirsko-traškega izvora (Skok I 1971, 100-101).

\section{3 *čoban "pastir»}

$\mathrm{V}$ jezikih tega areala se poleg domače besede za pastirja (alb. bari, rom. păstor, bol. nacmúp ipd.) pojavlja še beseda, ki je s prihodom Turkov na Balkan prišla v jezike karpatsko-balkanskega areala iz perzijskega jezika (Skok I 1971, 332) V sodobnih jezikih se beseda glasi: srb.-hrv. čòban(in), mak чобан, bol. чобáн, sln. nar. čôban, polj. czaban, ukr.

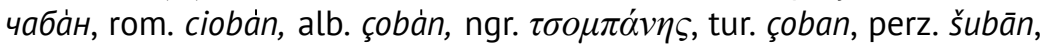
kar je enako z av. " fšupāna- < * fśú (čreda) in *pāna- (varuh) (Pokorny 2007, 2302) - v pomenu »tisti, ki varuje, skrbi za čredo«.

\section{4 "guša "sprednji del vratu«}

$\mathrm{Na}$ področju karpatsko-balkanskega areala besedo najdemo $\mathrm{v}$ naslednjih jezikih: srb.-hrv. güšsa, mak. zyma, bolg. zẏua, čiš. guša, rom. guşă,

\footnotetext{
${ }^{2}$ Na tem področju najdemo tudi posamične kraje, kot so Marindol, Miliči, Paunoviči, kjer so genetskojezikoslovno gledano štokavski govori (Šekli 2018, 384).
} 
alb. gushë, v pomenu »sprednji del vratu, tako človeškega kot živalskega; bolezensko povečana žleza ščitnica«, tudi sln. gôlša »bolezensko povečana žleza ščitnica; razširjeni del požiralnika pri pticah in nekaterih žuželkah«, istega izvora je tudi francoska beseda gosier, v pomenu »notranji del vratu (Georgiev et al. I 1971, 297). Beseda se je razvila iz latinskega geusiae (gingiva, dlesen) (Georgiev et al. I 1971, 297 in Skok I 1971, 638), v slovenski jezik naj bi beseda prišla iz ben. it. (Snoj 2009b).

\section{5 *katun »vas«}

Srb.-hrv. kàtūn »poletno pastirsko naselje«, mak. катун »poletno pastirsko naselje«, bolg. кату̀н »romsko naselje, romska hiša izven mesta«, alb. katund "vas« (prvotno »gorska vas«), rum. cătun »pastirsko naselje«, gr. $\chi \alpha \tau o v ́ v \alpha$ »poletno pastirsko naselje«, beseda se pojavlja tudi v stcsl. katounb (Skok II 1972, 64). Glede etimologije besede obstajata dve mnenji:

1) Jokl, s katerim se strinja tudi Skok, pravi, da se je beseda razvila $v$ albanščini in da je nastala iz predpone $k a$-, ki jo najdemo $v$ sklopu z glagoli, kapërcej »preskočiti«, kapërdij »pogoltniti, pogoltniti«, ter deležnika na -to glagola ndenj »stati« < ie. *tnto (Skok II. 1972, 64).

2) Miklošič je mnenja, da se je beseda razvila iz nar. lat. cantone »kot«, kar je sorodno s stcsl. kotb in je nastalo iz gal. canthos (Snoj 2009b). ${ }^{3}$

Zdi se, da so $v$ drugem primeru zgodovinske okoliščine spregledane. Beseda katun se namreč ne pojavlja v severnem delu areala, čeprav so jo s seboj verjetno prinesli vlaški pastirji. Poleg tega je $v$ srednjem veku na balkanskem področju katun predstavljal enoto družbenega in gospodarskega življenja, podobno zadrugam pri Južnih Slovanih. Tovrstnega termina pri karpatskih Vlahih ni (Luković 2016, 37). Če upoštevamo dejstvo, da so se tudi Albanci ukvarjali s pastirstvom (Stanišić 1995, 63) in da so stopali v stike z balkanskimi Vlahi (Desnickaâ 1976, 23), lahko domnevamo, da so besedo od Albancev prevzeli Vlahi in jo nato prenesli na druga področja. Zato je verjetnejša Joklova trditev, da beseda izhaja iz albanskega jezika.

\section{6 "kopil »izvenzakonski otrok«}

Srb-hrv. köpile »nezakonski otrok, neželeni otrok«, mak. копиле »nezakonski otrok«, bolg. ко́nеле »nezakonski otrok«, alb. kopil« nezakonski otrok, pameten in nemiren človek; odvečna veja, ki raste iz korenine že zrasle rastline, nar. dekle«, rom. copil »nezakonski otrok«, ngr. $\kappa o ́ \pi \varepsilon \lambda o \varsigma$ »dekle«, pojavlja se še slš. nar. kopyl’ »nezakonski otrok«, ukr. nar. кónuл »nezakonski otrok«. Skok meni, da se je beseda razvila v albanščini iz pripone ko- »slab« (primer. sanskr. $k a-$ ) in glagola pjell »roditi«, torej tisto, kar je »slabo rojeno« (II 1972,148), in naj bi po njegovem mnenju

\footnotetext{
${ }^{3}$ https://fran.si/iskanje?FilteredDictionarylds=193\&View=1 \& Query=\%2A
} 
izvirala iz pastirske terminologije. 0 tem priča pomen besede $v$ srbskih narečjih kopile »mladič zelo mlade samice« (Bošnjaković 1985, 123).

Po drugem tolmačenju je beseda slovanskega izvora. Avtorji Etimološkega slovarja slovanskih jezikov pravijo, da je psl. beseda *kopylb izvedena iz glagola *kopäti »odstranjevati odvečne mladike« (Stanišić 1995, 93). Beseda naj bi se iz poljedelstva razširila na družino in nato na druge plasti življenja (Stanišić 1995, 93). Če je ta domneva točna, je potem beseda sorodna z lit. kapóti »sekati«, stprus. enkopts »pokopati«, gr. $\kappa o ́ \pi \tau \omega$ »sekam, bijem«, vse < ide. *(s)kăp- »kopati, sekati« (Bezlaj II 1982, 64).

Glede na to, da v knjižnih jezikih beseda večinoma pomeni nezakonskega otroka, je bolj verjetna trditev avtorjev Etimološkega slovarja slovanskih jezikov. Temu v prid pričata tudi dejstvi, da se $v$ pastirstvu beseda pojavlja le $v$ narečjih ter da beseda $v$ albanščini pomeni 'odvečna sadika'.

\section{7 "ob(v)or »obor, obora«}

$\mathrm{V}$ jezikih karpatsko-balkanskega areala je prisotna v: srb.-hrv òbor, mak. обор, bolg. обор, sln. obòr, ukr. обopa, alb. oborr, rom. obor, v vseh jezikih s pomenom »nepokrit ograjen prostor za živali«, razen v albanščini, kjer pomeni »vrt». Od Slovanov so besedo prevzeli Romuni in Albanci (Skok II 1972, 538). Sorodno še s sln. obóra »ograjen rezervat v gozdu«. Prvotno *ob(v)ora je izpeljano iz glagola *ob(v)érti »zagraditi«, $<{ }^{*} o b$ »okoli, pri« in *vertî'»zapirati« (Snoj 2009b in Bezlaj II 1982, 235).

\section{8 *salaš »salaš«}

Srb.-hrv. sàlāš »kmetija daleč od mesta«, mak. caлau »kmetija daleč od mesta«, bolg. cáлаu »koča, zgrajena iz desk«, sln. zlasti v madžarskem okolju sálaš " posestvo s hišo in gospodarskimi poslopji daleč od gospodarskega bivališča«, slš. salaš »ograjen prostor za ovce s kočo za pastirje«, rom. săláş "začasno zavetičče«, tur. salaş »baraka za prodajo sadja«. Beseda je izposojena iz madž. szállás "prenočišče«, ki je izpeljanka iz madž. száll »vstopiti« (Bezlaj III 1995, 2015).

\section{9 *strunga »prostor za molžo ovc«}

Srb.-hrv. strüga »ograjen prostor za molžo ovc«, slš. strunga »ograjen prostor za molžo ovc«, pol. strąga »ograjen prostor v staji za molžo ovc«, rom. strungă »ograjen prostor v staji za molžo ovc«, ukr. nar. струннка »ograjen prostor v staji za molžo ovc«, alb. shtrungë »ozka steza v bližini vhoda v stajo, kjer se molzejo ovce«, rum. strungă »ograjen prostor v staji, kjer se molzejo ovce«. Po Miklošičevem mnenju je beseda izpeljana iz alb. glagola shtrëngoj »stisniti, zategniti« < lat. stringere (Skok III 1973, 148-149). Po Skokovem mnenju je osnovna oblika *stronga, ki naj bi bila ilirotraški prevoj nasproti lat. stringere (Skok III 1973, 149). 


\subsection{0 "šeleg »jagnje staro eno leto«}

Srb.-hrv. šiljeg, mak. шиле, bolg. ши́ле in alb. sheleg »jagnje, staro eno leto«. Etimologija te besede še vedno ni razložena. Polak jo povezuje s kavkaškimi jeziki, gruz. šveli »srnjak« (Stanišić 1995, 65). Skok po drugi strani navaja možnost, da je beseda slovanskega izvora, kar je razvidno iz besed sèlek (ki se uporablja v Srbiji) in sèletak (ki se uporablja v Liki) s pomenom »letošnje jagnje« < psl. * se lěto (Stanišić 1995, 65).

\subsection{1 *vatra »ogenj, ognjišče»}

Srb.-hrv. vätra »ogenj«, bolg. nar. вámpa »ogenj«, češ. nar. vatra »velikogenj v naravi«, slš. vatra »velik ogenj v naravi«, ukr. nar. вámpa »ognjišče, odprt pastirski ogenj v polju«, alb. vatër »ognjišče«, rom. vatră »ognjišče«, beseda se je po menju Desnickaje iz albanščine razširila v druge jezike. Ta naj bi se razvila iz lat. atrium »ognjišče« s protetičnim $v$ - po analogiji s starimi latinskimi prevzetimi besedami $v$ albanščini vaj »olje« < lat. oleum, varfër »revež« < lat. orphanus (Desnickaja v Stanišić 1995,69$)$. Če je domneva točna, je to naprej podobno z avest. *atras > perz. odar »ogenj«, arm. ariem »gorim« (Skok II 1972, 569).

Stanišić opozarja na dejstvo, da te besede ni v južnih govorih srbohrvaškega jezika ter $v$ makedonščini, kjer bi se po vsej verjetnosti pojavila $(1995,69)$. Treba je dodati, da besede ne pozna niti aromunščina, čeprav so aromunski pastirji bili v stiku z albanskim prebivalstvom.

Širši vpogled $v$ to vprašanje ponuja Jokl, s katerim se strinja Vinereanu $(2008,882)$, ki meni, da so besedo od Albancev prevzeli Romuni pred prihodom Slovanov. Beseda je potem iz romunščine prešla v druge jezike. S to razlago se odpravlja vprašanje diskontinuitete te izoglose, saj se je beseda iz romunščine kot jezika, ki se geografsko nahaja v središču karpatsko-balkanskega areala, lahko nemoteno razširila $v$ druge jezike.

\section{Sklep}

Obravnavane besede ponujajo v pogled $v$ stike med ljudstvi balkanskega in karpatskega območja. Na podlagi gibanja teh skupin, predvsem Vlahov, lahko sklepamo, kako so se besede prenašale.

Iz izbranih besed je razvidno, da so stiki med etničnimi skupinami tega področja bili zelo pestri, saj prevzemanje ni potekalo iz enega jezika $v$ druge, temveč je ta proces bil vzajemen.

Besede, ki se pojavljajo v narečjih slovenskega jezika, so posledica stikov Slovencev in drugih ljudstev, ki so na slovensko ozemlje prišli v času turških upadov na Balkan, medtem ko so besede, ki se pojavljajo tudi v knjižni slovenščini prej posledica stika s sosednjimi narodi (Furlani, Italijani in Madžari).

Obravnavane besede lahko razdelimo v več skupin, in sicer glede na izvor ter njihovo ustrezno etimologiziranost. 
Glede na izvor jih lahko razdelimo na:

a) besede albanskega izvora: *vatra;

b) besede madžarskega izvora: *salaš;

c) besede slovanskega izvora: *ob(v)or;

d) besede romanskega izvora: " guša, ${ }^{*}$ strunga;

e) besede perzijskega izvora: " čoban;

f) besede nejasnega izvora in tiste, ki jim različni avtorji pripisujejo različen izvor: *balega, ${ }^{*}$ katun, ${ }^{*}$ kopil, ${ }^{*}$ šeleg.

Glede na etimološko razlago:

a) ustrezno etimologizirane besede: *čoban, " $g u s ̌ a, ~{ }^{*} o b(v) o r,{ }^{*}$ strunga, "salaš, "vatra;

b) besede, ki niso ustrezno etimologizirane: *balega, * šeleg;

c) besede, pri katerih obstajajo razhajanja: ${ }^{*} k a t u n,{ }^{*} k o p i l$.

Glede zadnjih dveh lahko dodamo:

a) pri besedi *katun ima najverjetneje prav Jokl, ki meni, da je beseda albanskega izvora. Glede na to, da se beseda pojavlja samo v balkanskih jezikih, medtem ko je jeziki karpatskega dela karpatsko-balkanskega areala ne poznajo, lahko sklepamo da je beseda albanskega izvora, saj bi v nasprotnem primeru, ki ga zagovarja Miklošič (da je beseda latinskega izvora), ta bila znana tudi dakoromunskim pastirjem, ki bi jo posledično s seboj prinesli na karpatsko območje;

b) Glede na to, da ima beseda *kopil v večini jezikov pomen nezakonskega otroka, je bolj verjetna trditev avtorjev Etimološkega slovarja slovanskih jezikov, v skladu s katero je psl. beseda *kopylb izvedena iz glagola *kopäti, kasneje pa se je uporaba besede iz poljedelstva razširila na družino in nato še na druga pomenska polja. Temu v prid govorita tudi dejstvi, da se $v$ pastirstvu beseda pojavlja le $v$ narečjih in da $v$ albanščini pomeni odvečna sadika.

Ker je za določene besede težko ali nemogoče določiti izvor, ostaja še veliko prostora za nadaljnje raziskave.

Literatura

Bernštejn 1988. - Бернштейн С. Б., Клепикова Г. П. 1988. Общекарпатский диалектологический атлас, выпуск 2. Москва: Наука. [Bernštejn S. B., Klepikova G. P. 1988. Obŝekarpatskij dialektologičeskij atlas, vypusk 2. Moskva: Nauka].

Bezlaj, France. 1982. Etimološki slovar slovenskega jezika II. K-O. Ljubljana: Slovenska akademija znanosti in umetnosti, Inštitut za slovenski jezik ZRC SAZU. 
Bezlaj, France. 1995. Etimološki slovar slovenskega jezika III. P-S. Ljubljana: Slovenska akademija znanosti in umetnosti, Inštitut za slovenski jezik ZRC SAZU.

Bogdan, Michael. 2011. Memory, Identity, Typology: An Interdisciplinary Reconstruction of Vlach Ethnohistory. Magistrska naloga. University of British Columbia.

Bošnjaković 1985. - Бошњаковић, Жарко. 1985. Пастирска терминологија Срема. Нови Сад: Филозофски факултет [Bošnjaković, Žarko. 1985. Pastirska terminologija Srema. Novi Sad: Filozofski fakultet].

Desnickaâ 1976. - Десницкая, Агня В.1976. - К интерпретации балканизмов в карпатской слексике.Кишинев:Общекарпатский диалектологический атлас. Лингвистические и этнографические тексты: 15-27 [Desnickaâ, Agnâ V. 1976. K interpretacii balkanizmov v karpatskoj leksike. Kišinev: Obŝekarpatskij dialektologičeskij atlas. Lingvističeskie i ètnografičeskie teksty: 15-27].

Georgiev 1971. - Георгиев, В. и др. 1971. Български етимологичен речник. Том I (A-3). София: БАН. [Georgiev, V. et al. 1971. Balgarski etimologichen rechnik. Tom I (A-Z). Sofiya: BAN].

Kahl, Thede. 2007. Überlegungen zum Prozess des Sprachproblems, unter besonderer Berücksichtigung der Balkanromania. Iaşi: Editura Alfa, 155-173.

Klemenčič, Simona. 2005. Starejše jezikovne povezave albanščine, baltščine in slovanščine. Doktorsko delo. Ljubljana: Filozofska fakulteta.

Klepikova 1975. - Клепикова, Г. П. 1975. Функционирование и генезис терминологии горного пастушества в славянских диалектах карпацкого ареала. Москва: Наука. 161-201 [Klepikova, G. P. 1975. Funkcionirovanie i genezis terminologii gornogo pastušestva $v$ slavânskih dialektah karpackogo areala. Moskva: Nauka].

Luković. 2014. - Луковић, Милош. 2014. Сточарска привреда као чинилаи обликовања народне културе Срба. Београд: Балканолошки институт CAHY [Luković, Miloš. 2014. Stočarska privreda kao činilac oblikovanja narodne kulture Srba. Beograd: Balkanološki institut SANU].

Luković, Miloš. 2015. „Sezonowe migracje pasterzy na Bałkanach: charakter, historia, transformacje“. Res Historica 40: 61-95.

Luković, Miloš. 2016. „Self-Government Institutions of Nomadic and SemiNomadic Livestock Breeders in the Balkans and in the Carpathian Regions in the Late Medieval and early Modern Periods“. Res Historica 41: 51-94.

Micle, Ionel Călin. 2013. From Carpathians to Pindus: Transhumance - A Bridge Between Romanians and Aromanians. Pridobijeno s https://www. researchgate.net/publication/307466551_FROM_CARPATHIANS_TO_ PINDUS_TRANSHUMANCE_-_A_BRIDGE_BETWEEN_ROMANIANS_ĀND_AROMANIAN

Mirdita, Zef. 2007.„Vlasi, polinomičan narod“. Povjesni prilozi 26 (33): 249-269. 
Mutavdžić 2019. - Мутавџић, Предраг. 2019. Балканологија: скрипта. Београд: Филолошки факултет. [Mutavdžić, Predrag. 2019. Balkanologija: skripta. Beograd: Filološki fakultet].

Oczko, Anna. 2016. „Traces of Vlach migrations in the Toponymy of the Polish Podtatrze Region“. Res Historica 41: 151-158.

Pokorny, Julius. 2007. Proto-Indo-European Etymological Dictionary. IndoEuropean language revival association.

Radan in dr. 2016. - Радан, Михај Н. и Миљана-Радмила Ускату. 2016. „Карашевска пастирска терминологија (са посебним освртом на страни утицај у њој)." У Језици и културе у времену и простору V, уреднице Снежана Гудурић и Марија Стефановић, 55-65. Нови Сад: Филозофски факултет [Radan, Mihaj N. i Miljana-Radmila Uskatu. 2016. „Karaševska pastirska terminologija (sa posebnim osvrtom na strani uticaj u njoj)". U Jezici i kulture u vremenu i prostoru $V$, urednice Snežana Gudurić i Marija Stefanović, 55-65. Novi Sad: Filozofski fakultet].

Rakić-Milojković. 1993. - Ракић-Милојковић, Софија. 1993. „Пастирска терминологија Кривовирског Тимока“. Српски дијалектолошки зборник 29: 11-148 [Rakić-Milojković, Sofija. 1993. „Pastirska terminologija Krivovirskog Timoka“. Srpski dijalektološki zbornik 29: 11-148].

Smerdel, Inja. 1989. Ovčarstvo na pivki: transhumanca od srede 19. do srede 20. stoletja ali trije »ovčarji«: etnološka razprava. Koper: Lipa.

Snoj, Marko. 2009a. Etimološki slovar slovenskih zemljepisnih imen. Ljubljana: Modrijan; Založba ZRC.

Snoj, Marko. 2009b. Slovenski etimološki slovar. Ljubljana: Slovenska akademija znanosti in umetnosti, Inštitut za slovenski jezik ZRC SAZU. Pridobljeno s: https://fran.si/iskanje?FilteredDictionarylds=193\&View=1\&Query=\%2A

Skok, Petar. 1971. Etimologijski rječnik hrvatskoga ili srpskoga jezika I,A-J.Zagreb: Jugoslavenska akademija znanosti i umjetnosti.

Skok, Petar. 1972. Etimologijski rječnik hrvatskoga ili srpskoga jezika II, K-poni. Zagreb: Jugoslavenska akademija znanosti i umjetnosti.

Skok, Petar. 1973. Etimologijski rječnik hrvatskoga ili srpskoga jezika III, poni-Ž. Zagreb: Jugoslavenska akademija znanosti i umjetnosti.

Stanišić 1995. - Станишић, Вања. 1995. Српско-албански језички односи. Београд: Балканолошки институт САНУ. [Stanišić, Vanja. 1995. Srpskoalbanski jezički odnosi. Beograd: Balkanološki institut SANU].

Šekli, Matej. 2018. Tipologija lingvogenez slovanskih jezikov. Ljubljana: ZRC SAZU, Inštitut za slovenski jezik Frana Ramovša.

Šekli, Matej. 2019. „Spoznaj svoj jezik in svojega soseda“. V Slovenski jezik in njegovi sosedje: zbornik Slavističnega društva Slovenije 29, uredila Matej Šekli in Lidija Rezoničnik, 9-12. Ljubljana: Zveza društev Slavistično društvo Slovenije.

Vinereanu, Mihai. 2008. Dicționar etimologic al limbii române: pe baza cercetărilor de indo-europenistică. Bucureşti: Alcor Edimpex. 
Dodatna literatura

Atanasov 2002. - Атанасов Васил и др. 2002. Български етимологичен речник. Tом VI (крес1-много1). София: БАН. [Atanasov Vasil et al. 2002. Balgarski etimologichen rechnik. Tom VI (kres1-mnogo1). Sofiya: BAN].

Bezlaj, France. 1977. Etimološki slovar slovenskega jezika I. A-K. Ljubljana: Slovenska akademija znanosti in umetnosti, Inštitut za slovenski jezik ZRC SAZU.

Budzieszewska, Wanda. 1983. Stownik bałkanizmów w dialektach Macedonii Egejskiej. Warszawa: Wydawnictawa Uniwersitetu Warszawskiego.

Dicţionar explicativ al limbii române. Dostopno na https://dexonline.ro/

Digitalen rečnik na makedonskiot jazik - Дигитален речник на македонксиот јазик. Dostopno na http://www.makedonski.info/

Fjalori i gjuhës shqipe. Dostopno na https://fjalorthi.com/

Georgiev 1979. - Георгиев, В. И. и др. 1979. Български етимологичен речник. Том II (И-крепя). София: БАН. [Georgiev, V. І. et al. 1979. Balgarski etimologichen rechnik. Tom II (I-krepya). Sofiya: BAN].

Georgiev 1986. - Георгиев, В. И. и др. 1986. Български етимологичен речник. Том III (крес1-много1). София: БАН. [Georgiev, V. I. et al. 1986. Balgarski etimologichen rechnik. Tom III (kres1-mnogo1). Sofiya: BAN].

Istarski rječnik. Dostopno na http://www.istarski-rjecnik.com/

Rechnik na balgarskiya ezik - Речник на българския език. Dostopno na https:// ibl.bas.bg/

Slovnik ukraïnskoї movi - Словник українскої мови. Dostopno na http://sum. in.ua/

Slovníkový portál Jazykovedného ústavu L'. Štúra. Dostopno na https://slovnik. juls.savba.sk/

Soboleva 2009. - Соболева, А. Н. 2009. Малий диалектологический атлас балканских язиков, Том III. Санкт Петербург: Наука. [Soboleva, A. N. 2009. Malij dialektologičeskij atlas balkanskih âzikov, Tom III. Sankt Peterburg: Nauka].

Vujanić 2011. - Вујанић, Милица и др. 2011. Речник српскога језика. Нови Сад: Матица српска. [Vujanić, Milica i dr. 2011. Rečnik srpskoga jezika. Novi Sad: Matica srpska].

Wietiki słownik języka polskiego. Dostopno na https://wsjp.pl/ 


\author{
Aleksandar Trifunović \\ Univerzitet u Ljubljani \\ Filozofski fakultet \\ Slovenija \\ aleksandartrifunovic3@gmail.com
}

\author{
O ETIMOLOGIJI IZABRANIH REČI IZ PASTRISKE \\ TERMINOLOGIJE KARPATSKO-BALKANSKOG AREALA
}

Transhumantno stočarstvo je do dvadesetog veka za neke žitelje Balkanskog poluostrva predstavljalo način života i bilo glavni izvor njihovih prihoda. Zbog takvog načina života su se Vlasi balkanskog i karpatskog područja svake godine selili na letnje i zimske pašnjake. Takav način života je neizostavno doveo i do kontakta transhumantnih pastira s drugim narodima. Njihov kontakt je doveo do kulturne i jezičke razmene, što je ostavljalo trag u njihovim jezicima, a rezultati kontakata su najočigledniji na leksičkoj ravni jezika tih naroda. Ovaj članak će se baviti izabranim rečima iz pastirske terminologije karpatsko-balkanskog areala.

Ključne reči: Vlasi, pastiri, trahnumanca, Balkan, karpatsko-balkanski areal

\author{
Aleksandar Trifunović \\ University of Ljubljana \\ Faculty of Philosophy \\ Slovenia \\ aleksandartrifunovic3@gmail.com
}

\title{
THE ETYMOLOGY OF SELECTED WORDS FROM THE PASTORAL TERMINOLOGY OF THE CARPATHIAN-BALKAN AREA
}

Until the $20^{\text {th }}$ century, transhumant animal husbandry was a way of life and the main source of income for some inhabitants of the Balkan Peninsula. Due to such a way of life, the Vlachs of the Balkan and Carpathian area moved to summer and winter pastures every year. Such a way of life inevitably brought transhumant shepherds in contact with other ethnic groups. The contacts led to cultural and linguistic exchange, which left an imprint on their languages. Accordingly, the effects of the contacts are the most apparent at the lexical level of their languages. This paper deals with selected words from the pastoral terminology of the Carpathian-Balkan area.

Keywords: Vlachs, shepherds, transhumance, Balkans, CarpathianBalkan area 